United States has a particular, but urgent, need to devise a coherent policy on relations with Latin America, shamefully neglected in the past eight years. But, now that Brady has spoken, all this has to be arranged by tomorrow or, at the latest, the day after tomorrow. This is a slipshod way in which to deal with such an important matter.

\section{All greens now}

Politicians anxious about the environment seem no more ready than their predecessors to make prudent choices.

THE most obvious intellectual weakness of the environmental movement, already apparent in its first flowering in the late 1960s, is its habitual failure to tell what is important. So much is now clear in the general response to the otherwise welcome recognition by senior politicians that the greenhouse effect must be taken seriously. Suddenly, it seems, a whole range of public policy is legitimately to be dominated by what are called ecological imperatives. One result will be that public and private resources will be squandered needlessly. Another is that our capacity to deal with the important problems will be seriously impaired.

Here is a sample of how the wind is blowing. A few months ago, the government of the Netherlands decided to require that new motor cars should meet emission standards more stringent than those agreed by the European Community in a famous compromise reached only with the greatest difficulty four years ago - and to which the Dutch were then a party. The result (unless the decision is overturned by the European Court of Justice) may be that Dutch motor-cars will in future emit less pollution while the rest of Europe reverts to its older ways. In West Germany (see page 194), self-evidently innocuous experiments with genetically engineered plants must be carried out in a limbo that will be removed only when there is a legislation on the subject, likely to be the most restrictive in Europe. In Britain last week, a plan to build a railway link between the channel tunnel and the rest of Britain was hastily rerouted to meet environmental objections, at an estimated extra cost of $£ 500$ million. Mrs Margaret Thatcher, the British prime minister, is both consistent and right to say that the extra cost must be met by those who use the railway, which is unlikely to be commissioned until several years after the tunnel. But, on the Principle of the Conservation of Money, the extra $£ 500$ million spent to preserve the gentility of rural Kent will be $£ 500$ million less to spend on other worthwhile causes.

Collective sanity requires a better sense of proportion. All environmental protection in which governments are involved is at bottom a public purchase - one made on behalf of a whole community with resources drawn from it either by taxation or by the payment of user fees. The government of the Netherlands, for example, has implicitly arranged that the costs of reducing exhaust emissions will be met by Dutch motorists, who will pay more for their cars and more for their fuel. (The Netherlands may hope to recoup some of the extra cost if Dutch motormanufacturers find they have an edge in the domestic market-place over their competitors.)

The British railway to the channel tunnel is in the same case. The preservation of a corridor through Kent has been judged worth $£ 500$ million, which the operators of the railway will have to find and then recover by means of a tax (extra fare) on the railway's users. Meeting the extra capital cost out of public funds (which the British government will be asked to do) would simply redistribute the burden.

Sadly, in all of these decisions, the communities on whose behalf governments have acted (or, in the case of West Germany, failed to act) have not been presented with a choice. Yet the extra cost of the British railway far exceeds what would be the cost of drawing up and enforcing legislation to make British farm foodstuffs free from Salmonella infection but may be a more prudent investment. So should not the governments committing these substantial sums of money ostensibly in the public interest ask the communities they are supposed to serve what choice they should make between the alternatives? Surprisingly, even the British government, which likes to think of itself as strong, seems to prefer to be pushed about in one direction or another as local or otherwise special interests make themselves heard.

The conversion of people such as Thatcher to a proper concern about the greenhouse effect should have engendered a more resolute view of environmental costs, but has not. Yet the crude arithmetic of the case is as accessible as the back of the nearest envelope. Suppose there is eventually a carbon dioxide convention, and that countries such as Britain have to generate all their electricity from fuels other than hydrocarbons. That could entail building 50 million $\mathrm{kW}$ of nuclear generating capacity over say 20 years, which would work out at an investment of $£ 5,000$ million a year if the extra cost of nuclear generating capacity is merely $£ 2,000$ a kilowatt. That simple arithmetic does not imply that nuclear capacity is the only alternative, but unconventional sources of electricity would probably on present form be more expensive, nor does it allow for the replacement of fossil fuels in other energyconsuming machinery, vehicles for example.

In short, if it should eventually be necessary to reduce carbon dioxide emissions, the costs are likely to be orders of magnitude greater even than the sums now being frittered away on the railway to the channel tunnel. One way of responding to that dilemma is to say that if measures to combat the greenhouse effect are likely to cost several thousand million pounds a year, $£ 500$ million or so for Kent is mere chicken-feed. But that is also the route to national impoverishment. The more prudent course is to require than people should choose. Thatcher, above all politicians of her persuasion, should be eager to remind people that that is not merely their right but their duty. 